\title{
Effect of temperature on the biology of Noctua atlantica (Lepidoptera: Noctuidae), a species endemic to the Azores
}

\author{
Maria Luísa Melo OliVeira, Virgílio Vieira and Patrícia Ventura Garcia \\ CIRN, Departamento de Biologia, Universidade dos Açores, 9501-801 Ponta Delgada, Açores, Portugal; \\ e-mail: ziza@notes.uac.pt; vvieira@notes.uac.pt; patriciag@notes.uac.pt
}

Key words. Development, oviposition, longevity, emergence, mortality, day-degrees

\begin{abstract}
The effect of constant temperatures $\left(5,10,15,20,25\right.$ and $\left.30^{\circ} \mathrm{C}\right)$ on several biological parameters of Noctua atlantica (Warren), a noctuid endemic to the Azores, was studied using an artificial diet as food. At 5 and $30^{\circ} \mathrm{C}$ no eggs hatched. Developmental time (egg, larval, pupal and egg-to-adult) differed significantly at each temperature. Pupal weight (males and females) was significantly higher at $10^{\circ} \mathrm{C}$ and lower at $25^{\circ} \mathrm{C}$. Adult longevity and the pre-oviposition period were longer at 10 and $15^{\circ} \mathrm{C}$ and differed significantly from those observed at higher temperatures. The mean number of eggs laid per female (fecundity) was significantly higher at $15^{\circ} \mathrm{C}$, and lower at $25^{\circ} \mathrm{C}$. Pupal weight (males and females) was positively correlated with larval, pupal, egg-to-adult developmental times and with adult longevity. Female pupal weight was also positively correlated with the pre-oviposition period and with fecundity. Temperatures ranging from 10 to $20^{\circ} \mathrm{C}$ are the most suitable for the development of $N$. atlantica, suggesting that this species is well adapted to the climatic conditions found in their natural habitat. The number of day-degrees required for the development from egg to adult emergence was $1428.57 \mathrm{D}^{\circ}$, and $117.79 \mathrm{D}^{\circ}$ for the pre-oviposition period. Thus, $N$. atlantica can have two generations per year at high altitudes $(550$ or $800 \mathrm{~m})$ in the Azores.
\end{abstract}

\section{INTRODUCTION}

Noctua atlantica (Warren) (Lepidoptera: Noctuidae) is endemic to the Azores (Warren, 1905; Meyer, 1991, 1995; Hacker \& Schmitz, 1996; Vieira, 1997, 1998) and is found on eight of the nine islands of the archipelago (Carvalho et al., 1999).

Its host plants are unknown, but $N$. atlantica is found in the Azorean ecosystem "Laurisilva". Adults are present throughout the year, except during winter at medium and high altitudes (Araújo, 1994; Vieira \& Silva, 1994; Vieira \& Tavares, 1994).

Lepidoptera native to the Azores were mostly surveyed for inventory purposes (Vieira, 1998). Recently, detailed studies of the community and biological characteristics of endemic noctuids, aimed at their conservation in the Azores, were undertaken.

To understand the annual life cycle and distribution of $N$. atlantica populations the influence of environmental factors, such as temperature, on development was studied. Temperature plays a critical role in determining the rate of development, survival and reproduction of insects (Olsen et al., 1998; Lysyk, 2000; Doerr et al., 2002). The rate of insect development is predictable using heat accumulation, based on day-degrees or physiological time (Wagner et al., 1984: Jones et al., 1997).

The objective of this study was to record the effect of temperature on mortality, developmental time, longevity and fecundity of $N$. atlantica. Additionally, a day-degree model was used to estimate the number of generations per year this species can achieve in its natural habitat.

\section{MATERIAL AND METHODS}

\section{Development and survivorship}

Adults of $N$. atlantica were collected overnight on Graminhais (S. Miguel-Azores, $800 \mathrm{~m}$ a.s.1.) using light traps (Pennsylvania type). Adult males and females were placed inside cages $(50 \times 50 \times 50 \mathrm{~cm})$ and supplied with an aqueous solution of sugar $(10 \%)$. All experiments were conducted in climatic chambers
(Versatile Environmental Test Chamber, Sanyo, MLR-350) at constant temperatures of: $5 \pm 1,10 \pm 1,15 \pm 1,20 \pm 1,25 \pm 1$ and $30 \pm 1{ }^{\circ} \mathrm{C}$. Photoperiod was maintained at $16 \mathrm{~L}: 8 \mathrm{D}$, while humidity was kept at $70 \pm 5 \%$ at each temperature. Egg development time was determined using eggs obtained daily from adults of $N$. atlantica. Eggs were disinfected in $10 \%$ formaldehyde solution for $20 \mathrm{~min}$ and rinsed with distilled water. Three replicates, each of 100 eggs, were then placed in plastic containers, and allowed to hatch; they were checked every day. The period from neonate larva to pupation was the larval development time. Larvae were kept in groups until the $3^{\text {rd }}$ instar, then, they were reared individually. Larvae were fed with small portions $\left(1 \mathrm{~cm}^{3}\right)$ of artificial diet (Poitout \& Bues, 1970, modified by Oliveira, 1991), which were renewed every two days. Pupae were individually weighed and caged in small clear glass containers $(4.5 \times 3 \mathrm{~cm})$. The mortality of larvae and pupae was recorded every day. Containers were checked twice a day (9:00 and 17:00 h) for emergence of adults. One male and one female were placed together in a clear glass container $(8 \times 5 \mathrm{~cm})$ to allow mating and check the pre-oviposition period (number of days between female emergence day and the day when the first egg was laid). The fecundity (number of eggs laid by each female) and adult longevity (males and females) were also monitored daily. A cotton ball containing an aqueous solution of sugar $(10 \%)$ was placed in each container, to nourish the adults.

\section{Day-degrees}

The recorded developmental times were: egg development time (oviposition to hatching), larval development time (hatching to pupation), and pupal development time (pupa to adult emergence) and pre-oviposition period. The threshold temperature for development was estimated by the $\mathrm{x}$-intercept method, i.e., through least squares regression of the mean development rate over temperature, and extrapolating the regression line back to the $\mathrm{x}$-axis. The day-degrees $\left(\mathrm{D}^{\circ}\right)$ required for development of each life stage were estimated using the method reported by Arnold (1959). 


\section{Weather variables}

The meteorological data, from two agro-climatic stations at 550 and $800 \mathrm{~m}$, were provided by the Institute of Meteorology/Azores. Calendar monthly averages of temperature recorded daily at 12:00 GMT for 30 years (1951-1980) were used.

\section{Statistical analysis}

All data were transformed by $\sqrt{ }(x+0.5)$ and compared using analysis of variance (ANOVA), followed by Scheffé tests with $P<0.05$, except the differences between the pupal weights of the sexes at each temperature, which were analysed using $t$-tests. Percentage of eggs that hatched was analysed using a Kruskal-Wallis test (Zar, 1996).

Pearson correlation analyses were performed between pupa weight and other variables. Mortality data was analysed using the Multiple Comparison test for Proportions (Zar, 1996). All analyses were performed using SPSS 10.0 Windows (SPSS Inc., 1999).

\section{RESULTS}

\section{Development and survivorship}

At 5 and $30^{\circ} \mathrm{C}$ no eggs of $N$. atlantica hatched and the highest percentage hatched at $15^{\circ} \mathrm{C}$ (Table1). At $10^{\circ} \mathrm{C}$ percentage of egg hatch was not determined since cannibalism occurred. Percentage of egg hatch decreased with increase in temperature (Table 1$)$, but not significantly $(F=1.330 ; \mathrm{df}=2,8 ; P=0.317)$.

TABle 1. Percentage (mean \pm SD) of $N$. atlantica eggs that hatched at $5,10,15,20,25$ and $30^{\circ} \mathrm{C}$.

\begin{tabular}{ccc}
\hline Temperature $\left({ }^{\circ} \mathrm{C}\right)$ & $\mathrm{n}$ & Hatched eggs $(\%)$ \\
\hline 5 & 406 & $0.00 \pm 0.00$ \\
10 & 418 & - \\
15 & 237 & $91.23 \pm 8.07$ \\
20 & 353 & $82.37 \pm 12.11$ \\
25 & 446 & $78.26 \pm 9.73$ \\
30 & 382 & $0.00 \pm 0.00$ \\
\hline
\end{tabular}

$N$. atlantica larval and pupal mortality were significantly influenced by temperature $(F=23.477$; df $=3,513 ; P<0.001)$. Larval mortality was significantly higher at $25^{\circ} \mathrm{C}$ and pupal mortality at the lowest temperature $\left(10^{\circ} \mathrm{C}\right)$ (Table 2$)$.

The number of days required for egg, larval, pupal and eggto-adult (total) development decreased significantly with increase in temperature $(F=8674.352 ; \mathrm{df}=3,342 ; P<0.001)$, $(F=1938.727 ; \mathrm{df}=3,342 ; P<0.001),(F=4049.504 ; \mathrm{df}=3$, 342; $P<0.001)(F=7606.543 ; \mathrm{df}=3,342 ; P<0.001)$ (Table $3)$.

Pupae were significantly heavier at $10^{\circ} \mathrm{C}$, and lightest at $25^{\circ} \mathrm{C}$ $(F=75.167 ; \mathrm{df}=3,342 ; P<0.001)$ (Table 4). At each temperature, the pupae of females were significantly heavier than those of males $\left(t=-3.192 ; \mathrm{df}=86 ; P=0.02 \mathrm{t}\right.$-test for $\left.25^{\circ} \mathrm{C}\right),(t=$
TABle 2. Percentage of mortality of larvae and pupae of $N$. atlantica at $10,15,20$ and $25^{\circ} \mathrm{C}$.

\begin{tabular}{crrrr}
\hline \multirow{2}{*}{ Temperature $\left({ }^{\circ} \mathrm{C}\right)$} & $\mathrm{n}$ & \multicolumn{3}{c}{ Mortality (\%) } \\
\cline { 3 - 5 } & & Larval & Pupal & Total \\
\hline 10 & 91 & $15.38 \mathrm{~b}$ & $33.77 \mathrm{a}$ & $43.96 \mathrm{a}$ \\
15 & 116 & $6.90 \mathrm{~b}$ & $6.48 \mathrm{~b}$ & $12.93 \mathrm{~b}$ \\
20 & 130 & $13.08 \mathrm{~b}$ & $6.19 \mathrm{~b}$ & $18.46 \mathrm{~b}$ \\
25 & 180 & $47.78 \mathrm{a}$ & $6.38 \mathrm{~b}$ & $51.11 \mathrm{a}$ \\
\hline
\end{tabular}

Means in each column that are followed by a different letter are significantly different $(P<0.05)$.

$-3.715 ; \mathrm{df}=104 ; P<0.001 \mathrm{t}$-test for $\left.20^{\circ} \mathrm{C}\right),(t=-7.482 ; \mathrm{df}=$ 99; $P<0.001 \mathrm{t}$-test for $\left.15^{\circ} \mathrm{C}\right)$ and $(t=-3.195 ; \mathrm{df}=49 ; P=0.02$ $\mathrm{t}$-test for $10^{\circ} \mathrm{C}$ ).

Longevity of the adults and pre-oviposition period were significantly affected by temperature $(F=166.158 ; \mathrm{df}=3,342 ; P$ $<0.001$ and $F=52.772 ; \mathrm{df}=3,109 ; P<0.001$, respectively). These two parameters were significantly longer at 10 and $15^{\circ} \mathrm{C}$ than at the higher temperatures (Table 4). The mean number of eggs laid per female was significantly higher at $15^{\circ} \mathrm{C}(F=$ 14.495; df $=3,137 ; P<0.001)($ Table 4).

TABLE 3. Development times (mean \pm SD) of egg, larval, pupal and egg-to-adult (total) stages of $N$. atlantica at 10, 15, 20 and $25^{\circ} \mathrm{C}$.

\begin{tabular}{rrrrrr}
\hline \multirow{2}{*}{$\mathrm{T}\left({ }^{\circ} \mathrm{C}\right)$} & $\mathrm{n}$ & \multicolumn{4}{c}{ Development time (days) } \\
\cline { 2 - 6 } & & \multicolumn{1}{c}{ Egg } & \multicolumn{1}{c}{ Larva } & Pupa & \multicolumn{1}{c}{ Total } \\
\hline 10 & 51 & $26.14 \pm 1.69 \mathrm{a}$ & $112.14 \pm 7.24 \mathrm{a}$ & $79.45 \pm 3.33 \mathrm{a}$ & $217.73 \pm 9.37 \mathrm{a}$ \\
15 & 101 & $14.57 \pm 0.54 \mathrm{~b}$ & $61.49 \pm 3.85 \mathrm{~b}$ & $35.62 \pm 4.55 \mathrm{~b}$ & $111.60 \pm 3.77 \mathrm{~b}$ \\
20 & 106 & $7.41 \pm 0.57 \mathrm{c}$ & $43.66 \pm 5.35 \mathrm{c}$ & $25.98 \pm 1.67 \mathrm{c}$ & $77.05 \pm 5.36 \mathrm{c}$ \\
25 & 88 & $6.39 \pm 0.49 \mathrm{~d}$ & $41.15 \pm 4.91 \mathrm{~d}$ & $17.16 \pm 1.53 \mathrm{~d}$ & $64.60 \pm 4.72 \mathrm{~d}$ \\
\hline
\end{tabular}

Means in each column that are followed by a different letter are significantly different $(P<0.05)$.

The weights of both male and female pupae were positively correlated with larval $\left(\mathrm{R}^{2}=0.393 ; \mathrm{df}=345 ; P<0.001\right)$, pupal $\left(\mathrm{R}^{2}=0.496 ; \mathrm{df}=345 ; P<0.001\right)$ and egg-to-adult development times $\left(\mathrm{R}^{2}=0.447 ; \mathrm{df}=345 ; P<0.001\right)$, and adult longevity $\left(\mathrm{R}^{2}\right.$ $=0.317 ; \mathrm{df}=345 ; P<0.001)$. Female pupal weight was also significantly correlated with pre-oviposition period $\left(\mathrm{R}^{2}=0.224\right.$; $\mathrm{df}=112 ; P=0.017$ ), and the mean number of eggs laid per female $\left(\mathrm{R}^{2}=0.272 ; \mathrm{df}=140 ; P=0.001\right)$.

\section{Day-degrees}

For the range of temperatures used, the lower temperature threshold $\left(\mathrm{t}_{\mathrm{b}}\right)$ and the day-degrees required for the development of $N$. atlantica were effectively determined by the linear model, as shown by the high coefficient of determination obtained for all the developmental stages (all $\mathrm{R}^{2}>0.93$ ) (Table 5).

The lower developmental thresholds $\left(\mathrm{t}_{\mathrm{b}}\right)$ for eggs, larvae and pupae were $5.69,0.36$ and $5.97^{\circ} \mathrm{C}$, respectively. The number of

TABLE 4. Pupal weight (males and females), adult longevity (males and females), pre-oviposition period and number of eggs laid per female (means $\pm \mathrm{SD}$ ) of $N$. atlantica at $10,15,20$ and $25^{\circ} \mathrm{C}$.

\begin{tabular}{crcccrcc}
\hline Temperature $\left({ }^{\circ} \mathrm{C}\right)$ & $\mathrm{n}$ & Pupal weight & Longevity of adults & $\mathrm{n}$ & Pre-oviposition period & $\mathrm{n}$ & Number of eggs/female \\
\hline 10 & 51 & $578.84 \pm 68.07 \mathrm{a}$ & $29.20 \pm 9.78 \mathrm{a}$ & 15 & $19.80 \pm 3.65 \mathrm{a}$ & 21 & $207.05 \pm 269.49 \mathrm{ac}$ \\
15 & 101 & $513.58 \pm 58.45 \mathrm{~b}$ & $33.51 \pm 13.93 \mathrm{a}$ & 44 & $17.73 \pm 7.64 \mathrm{a}$ & 47 & $473.62 \pm 300.87 \mathrm{~b}$ \\
20 & 106 & $517.15 \pm 77.36 \mathrm{~b}$ & $14.64 \pm 8.20 \mathrm{~b}$ & 33 & $7.82 \pm 2.20 \mathrm{~b}$ & 41 & $252.32 \pm 231.76 \mathrm{a}$ \\
25 & 88 & $409.25 \pm 76.30 \mathrm{c}$ & $7.69 \pm 3.14 \mathrm{c}$ & 21 & $6.10 \pm 1.58 \mathrm{~b}$ & 32 & $97.84 \pm 119.58 \mathrm{c}$
\end{tabular}

Means in each column that are followed by a different letter are significantly different $(P<0.05)$. 
TABLE 5. Temperature threshold $\left(\mathrm{t}_{\mathrm{b}}\right)$ and the day-degrees required for the development of the different stages of $N$. atlantica, with the respective coefficient of determination $\left(\mathrm{R}^{2}\right)$.

\begin{tabular}{lccccc}
\hline Stage & Intercept & Slope & $\mathrm{R}^{2}$ & $\mathrm{t}_{\mathrm{b}}$ & Day-degrees $\left(\mathrm{D}^{\circ}\right)$ \\
\hline Egg & -0.0478 & 0.0084 & 0.96 & 5.69 & 119.05 \\
Larva & -0.0004 & 0.0011 & 0.93 & 0.36 & 909.09 \\
Pupa & -0.0173 & 0.0029 & 0.99 & 5.97 & 344.83 \\
Egg-Adult & -0.0023 & 0.0007 & 0.99 & 3.29 & 1428.57 \\
Pre-oviposition & -0.0445 & 0.0085 & 0.92 & 5.24 & 117.79 \\
\hline
\end{tabular}

day-degrees required for the development from egg to adult emergence was $1428.57 \mathrm{D}^{\circ}$ and $117.79 \mathrm{D}^{\circ}$ to start of oviposition. For a complete generation a total of $1546.36 \mathrm{D}^{\circ}$ is necessary (Table 5).

For the calculation of the day-degrees required for the development of $N$. atlantica in the field, $\mathrm{t}_{\mathrm{b}}=3.29^{\circ} \mathrm{C}$ (obtained from the linear model for the total development time) and $1^{\text {st }}$ January as the initial date, because it is commonly used for agronomic purposes (López et al., 2001), were used. This and the meteorological data for two localities at 550 and $800 \mathrm{~m}$, indicate that

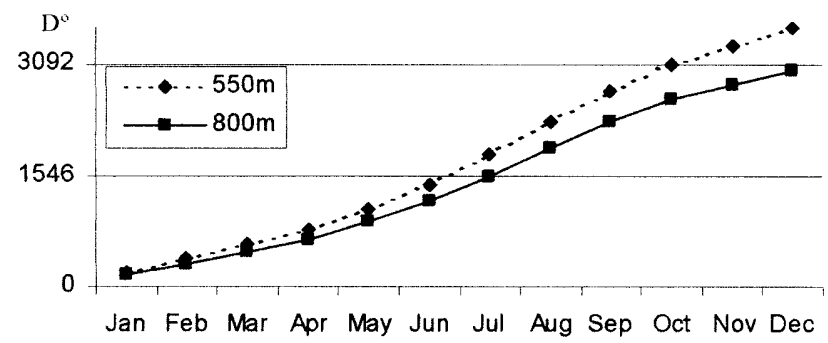

Fig. 1. The accumulation of day-degrees during the course of a year for $N$. atlantica, assuming a $t_{b}=3.29^{\circ} \mathrm{C}$, at localities at two altitudes (550 and $800 \mathrm{~m}$ ) on S. Miguel Island, Azores.

this species can have 2 generations per year in its natural habitat (Fig. 1)

\section{DISCUSSION AND CONCLUSIONS}

Although insects are not subject to constant temperatures in nature, a study under controlled conditions can provide a valuable insight into the population dynamics of a particular species (Summers et al., 1984). Our results demonstrate the effects of temperature on larval and pupal mortality, preimaginal development times, adult longevity, pre-oviposition period and fecundity of $N$. atlantica.

Low $\left(<10^{\circ} \mathrm{C}\right)$ or high $\left(>20^{\circ} \mathrm{C}\right)$ temperatures had a detrimental effect on $N$. atlantica fecundity, as is recorded by Mays \& Kok (1997) for Evergestis rimosalis (Lepidoptera: Pyralidae). At each temperature, female pupae were significantly heavier than male pupae. In contrast, the pupal weights of female and male Pseudaletia sequax (Lepidoptera: Noctuidae) do not differ (Foerster, 1996).

Development time was inversely related to temperature, when temperature is favourable, as observed in other Lepidoptera (Mcavoy \& Kok, 1992; Jones et al., 1997; Howell \& Neven, 2000; Tobin et al., 2001; Honek et al., 2002). Besides the inverse linear relationship between total development time and temperature, larval and pupal mortality was also significantly higher at the highest and lowest temperatures used. However, the mortality results show that $N$. atlantica larvae were less tol- erant of the highest temperature (i.e., $25^{\circ} \mathrm{C}$ ), and the pupae of the lowest temperature (i.e., $10^{\circ} \mathrm{C}$ ) used.

According to Honek et al. (2002) the thermal constants of insect species and even those of populations within a species vary greatly. Since these differences may be caused by bias in the experimental data, as well as biological variation, the relevance of these differences may be tested using the "rate isomorphy" hypothesis (Honek et al., 2002). According to this hypothesis the same proportion of the total development time is spent in each developmental stage independent of temperature. Consequently, the lower development threshold should be identical for all developmental stages. According to Honek et al. (2002), there are three reasons why extreme temperatures may violate rate isomorphy: i) mortality may differ at low temperatures; ii) the developmental time may be imprecisely measured at high temperatures; and, iii) a small bias in the developmental rates measured at the highest or lowest temperatures will cause a large shift in the lower development threshold. The discrepancy between the values of the lower developmental threshold of larvae and those of eggs and pupae, could be due to the high larval mortality observed at $25^{\circ} \mathrm{C}$. According to Wagner et al. (1984), mortality increases with temperature beyond the optimum, making the study of development difficult at high temperatures. Furthermore, the number of day-degrees required for $N$. atlantica larval development was high, which is to be expected when temperature is at or above the optimum (Wagner et al., 1984).

On the other hand, $N$. atlantica pupal weights were significantly higher at $10^{\circ} \mathrm{C}$, and lower at $25^{\circ} \mathrm{C}$. Honek et al. (2002) also record a decrease in Autographa gamma (Lepidoptera: Noctuidae) pupal weight with increase in temperature. Our results and those of these authors, show the temperature at which insects grow to the largest body size is always below the optimum for development time and fecundity. In $N$. atlantica the highest fecundity was achieved at $15^{\circ} \mathrm{C}$.

Our results indicate that $N$. atlantica is adapted to the temperatures $\left(8\right.$ to $\left.20^{\circ} \mathrm{C}\right)$ recorded in their natural habitat. Larvae are found in the field usually during late Winter and Spring, when ambient temperatures are low (ranging from 9-14 ${ }^{\circ} \mathrm{C}$ ) and pupae and adults during Summer, when temperatures are high (around $18^{\circ} \mathrm{C}$ ). As predicted by the lower developmental threshold for the eggs $\left(\mathrm{T}_{\mathrm{b}}=5.69^{\circ} \mathrm{C}\right)$, no eggs of $N$. atlantica hatched at $5^{\circ} \mathrm{C}$.

As suggested by Wagner et al. (1984) and Briere \& Pracros (1998) a linear model is useful because it is easy to use and requires minimal data. This model can be used for field predictions when extreme field temperatures rarely occur (Worner, 1992). In the Azores, at middle and high altitudes (where $N$. atlantica occurs), the average monthly temperatures vary between 8 and $20^{\circ} \mathrm{C}$. Therefore, according to these authors and our results, the linear model should be suitable for predicting population fluctuations of $N$. atlantica. According to this model, $N$. atlantica can have up to two generations per year on $\mathrm{S}$. Miguel, with overlapping generations due to the high developmental heterogeneity of the population.

In future, the effect of other factors that significantly influence development rates and other biological parameters, such as photoperiod, diet and food availability, will be studied in order to better understand and protect the endemic Lepidoptera in our Region.

\section{REFERENCES}

AraúJo M.G. 1994: Bioecologia de Mythimna unipuncta (Haworth) na Ilha Terceira e curva de voo de outros Noctuídeos. Dissertation, Universidade dos Açores, Açores, 89 pp. 
ARnold C.Y. 1959: The determination and significance of the base temperature in a linear heat unit system. Proc. Am. Soc. Hortic. Sci. 74: 430-445.

Briere J.F. \& Pracros P. 1998: Comparison of temperaturedependent growth models with the development of Lobesia botrana (Lepidoptera: Tortricidae). Environ. Entomol. 27: 94-101.

Carvalho J.P., Vieira V.F. \& Carvalho M.U. 1999: Borboletas Nocturnas dos Açores. Amigos dos Açores, Açores, 115 pp.

Doerr M.D., BrunNer J.F. \& Jones V.P. 2002: Temperaturedependent development of Lacanobia subjuncta (Lepidoptera: Noctuidae). Environ. Entomol. 31: 995-999.

FoERSTER L.A. 1996: Efeito da temperatura no desenvolvimento das fases imaturas de Pseudaletia sequax Franclemont (Lepidoptera: Noctuidae). Ann. Soc. Entomol. Brazil 25: 27-32.

HaCKer H. \& SChMitz W. 1996: Fauna und Biogeographie der Noctuidae des makaronesischen Archipels. Esperiana 4: $167-221$.

HoneK A., Jarosik V., Martinkova Z. \& Novak I. 2002: Food induced variation of thermal constants of development and growth of Autographa gamma (Lepidoptera: Noctuidae) larvae. Eur. J. Entomol. 99: 241-252.

Howell J.F. \& Neven L.G. 2000: Physiological development time and zero development temperature of the codling moth (Lepidoptera: Tortricidae). Environ. Entomol. 29: 766-772.

Jones V.P. CARrie H.M. \& CAPrio L.C. 1997: Life tables for the koa seedworm (Lepidoptera: Tortricidae) based on degree-day demography. Environ. Entomol. 26: 1291-1298.

López C., Sans A., Asi L. \& Eizaguirre M. 2001: Phenological model for Sesamia nonagrioides (Lepidoptera: Noctuidae). Environ. Entomol. 30: 23-30.

LysyK T.J. 2000: Relationships between temperature and life history parameters of Muscidifurax raptor (Hymenoptera: Pteromalidae). Environ. Entomol. 29: 596-605.

MaYs W.T. \& KoK L.T. 1997: Oviposition, development, and host preference of the cross-striped cabbageworm (Lepidoptera: Pyralidae). Environ. Entomol. 26: 1354-1360.

Mcavoy T.J. \& KoK L.T. 1992: Development, oviposition, and feeding of the cabbage webworm (Lepidoptera: Pyralidae). Environ. Entomol. 21: 527-533.

MeYer M. 1991: Les Lépidoptères de la région macaronésienne. II - Liste des Macro-Hétérocères observés en juillet-août 1990 aux Açores (Lepidoptera: Geometridae, Sphingidae, Noctuidae). Linn. Belgica 13: 117-134.
MeYer M. 1995: The Lepidoptera of the macaronesian region. VI Biogeographical aspects of Macrolepidoptera in northern Macaronesia (Madeira, Azores). Bol. Mus. Mun. Funchal 4: 441-453.

Oliveira L. 1991: Bioecologia de Apanteles militaris (Walsh, 1861) (Hymenoptera, Braconidae). Dissertation, Universidade dos Açores, Açores, 72 pp.

Olsen K.N., Cone W.W. \& Wright L.C. 1998: Influence of temperature on Grape Leafhoppers in South central Washington. Environ. Entomol. 27: 401-405.

Poitout S. \& Bues R. 1970 : Élevage de plusieurs espèces de Lépidoptères Noctuidae sur milieu artificiel riche et sur milieu artificiel simplifié. Ann. Zool. Ecol. Anim. 2: 79-91.

SPSS Inc. 1999: SPSS Base 10.0 Aplications Guide. Copyrigth of SPSS Inc., USA.

Summers C.G., Coviello R.I. \& Gutierrez A.P. 1984: Influence of constant temperature on the development and reproduction of Acyrthosiphon kondoi (Homoptera: Aphididae). Environ. Entomol. 13: 236-242.

Tobin P.C., Nagarkatti S. \& Saunders M.C. 2001: Modeling development in grape berry moth (Lepidoptera: Tortricidae). Environ. Entomol. 30: 692-699.

VIEIRA V. 1997: Lepidoptera of the Azores islands. Bol. Mus. Mun. Funchal 49: 5-76.

VIEIRA V. 1998: Biogeografia dos Lepidopteros (Insecta, Lepidoptera) dos Açores. Rev. Biol. (Lisboa) 16: 87-106.

VIEIRA V. \& Silva L. 1994: Rhopalocera and Heterocera (Insecta, Lepidoptera) observed in four islands of the Azores. Bol. Mus. Mun. Funchal 46: 85-94.

Vieira V. \& TAVARES J. 1994: A checklist of the Lepidoptera from Corvo island (Azores). Açoreana 8: 79-89.

Wagner T.L., Wu H-I., Sharpe P.J., Schoolfield R.M. \& Coulson R.N. 1984: Modeling insect development rates: a literature review and application of a biophysical model. Ann. Entomol. Soc. Am. 77: 208-225.

WARREN W. 1905: Lepidoptera collected by W.R. Ogilvie-Grant on the Azores and Madeira in 1903. Nov. Zool. 12: 439-447.

WORNER S.P. 1992: Performance of phenological models under variable temperature regimes: consequences of the Kaufmann rate summation effect. Environ. Entomol. 21: 689-699.

ZAR J.H. 1996: Biostatistical Analysis. Prentice-Hall, London, $661 \mathrm{pp}$.

Received October 17, 2003; revised February 23, 2004; accepted April 19, 2004 